\title{
Analysis of how agile manufacturing capabilities could be used differently in plants within the footloose and rooted subnetworks of the global production network
}

\author{
Sepvina Mutikasari ${ }^{*}$ \\ Faculty of Economics and Business, University of Groningen, Groningen, Netherlands
}

\section{Keywords \\ AM \\ GPN \\ Capabilities \\ Subnetworks}

Received: 6 May 2019

Accepted: 7 August 2019

Published: 31 October 2019

\begin{abstract}
This paper provides a literature review to investigate how Agile Manufacturing (AM) capabilities could be used in different plants within a company's Global Production Network (GNP). To do this, this paper makes use of Ferdows, Vereecke, and De Meyer (2016) subnetworks positions framework. Each of the subnetwork positions has its manufacturing characteristics and missions. From the four subnetworks, this paper focused on the main two, footloose and rooted. Seventeen articles were analyzed, and this paper found four major AM capabilities categories: responsiveness, flexibility, integration, and competency. Each of the AM capabilities categories could be used differently in each subnetworks depending on the focus factors emphasized in each category. With that, this paper has presented how AM system capabilities could help plants in the footloose and rooted subnetworks to achieve their missions. Further, this study provides an early phase to understand how AM system could accommodate different plants positions in the GPN. This study also set out an insight that, despite being founded 29 years ago, AM system with its capabilities is still relevant to be continuously implemented in the present time. This paper does not provide any empirical validation yet for the findings. Thus, this paper also provides avenues for future research.
\end{abstract}

(C) 2019 The Author(s). Published by TAF Publishing.

\section{INTRODUCTION}

AM concept was born in 1991 and known with its capabilities to deal with volatile market conditions and seize the opportune side of changing business circumstances (Luekveerawattana, 2016; Sharifi \& Zhang, 2001). In respect of changing circumstances, nowadays, the GPN of a typical manufacturing company are becoming more fragmented in terms of locations and missions (Ferdows et al., 2016). Thus, the question now is on how manufacturing companies could identify and utilize the relevant AM system capabilities to deal with the said situation.

Up to date, many researchers have done studies regarding the implementation of the AM system. For example, Tan (1998) studied the implementation AM system in regards to management of variability. Sharifi and Zhang (2001) proposed a methodology for achieving agility in manufacturing organizations in general. Further, several other re- searchers also suggested various ideas and frameworks on how AM could be implemented in different areas (Dubey \& Gunasekaran, 2015; Goldman, Nagel, \& Preiss, 1995; Nagel, 1992; Yusuf, Sarhadi, \& Gunasekaran, 1999).

Despite the amount of the extant literature mentioned above, there is still a lack of literature that emphasized directly about how AM system could be implemented in plants concerning the current GPN situation mentioned before. This is important because companies' production plants could utilize and maximize the capabilities carried by their manufacturing system if they know what to implement in the right production plants (Nuriansyah, Juniar, \& Redawati, 2017; Sharifi \& Zhang, 2001). Thus, this paper proposes to address the gap by presenting investigations of how AM system capabilities could be used in different company's production plants within the company GPN.

To do this, this paper use the plant subnetwork positions

\footnotetext{
* corresponding author: Sepvina Mutikasari

†email: s.mutikasari@student.rug.nl
} 
framework developed by Ferdows et al. (2016). Ferdows et al. (2016) suggested that a company's GPN can be delayered into four different subnetworks positions, which makes them more manageable for managers. The framework is divided based on the complexity of the product produced and the production process used by plants in the respective subnetwork. Each of the subnetwork positions has its own manufacturing characteristics and missions. The four subnetwork positions in the framework are process innovation, rooted, low investment, and footloose. However, this paper will only focus on the footloose and rooted subnetwork positions. These two highlighted because a subnetwork should typically be on the diagonal, "move from being proprietary and complex (rooted) to become commonly available and standardized (footloose)" (Ferdows, 2008).

The principal objectives of this paper are first, to carry out a literature review study to understand what are the capabilities carried by implementing AM system. Second, this paper seeks to know how AM capabilities could be used in different subnetwork positions and what makes them differ. This can be done by aligning those AM capabilities and approaches with different missions between footloose and rooted subnetworks by Ferdows et al. (2016). By doing this alignment analysis, this paper wishes to help managers to understand how these AM capabilities could help plants in each subnetwork to fulfill their primary roles and missions. Thereby, this paper wish they could maximize the benefits of capabilities carried by the AM system. These objectives formulated in the following research question:

- "How does the use of AM capabilities differ within the context of plants in footloose and rooted subnetworks of the GNP?"

The remainder of this paper is structured as follows. The next section discusses the theoretical framework of all the concepts used. Section 3 presents the methodology for reviewing the extant literature of AM. Section 4 reports the findings of the AM capabilities and the two subnetworks positions. Discussions and conclusions of the findings follow in the next parts. Finally, the concluding section of the paper also discusses the implications, limitations, and future research directions.

\section{LITERATURE REVIEW}

This section elaborated all the key concepts in light of the research question mentioned in the introduction part. Started with each of their definition from the extant literature, then followed by the possible linkage between the concepts.

\section{AM}

The concept of the AM enterprise was born and introduced as the solution for maintaining competitive advantage due to the constant increase of unexpected changes in the business environment (Boonvut, 2017; Nagel, 1992). When talking about the definition of AM, many authors have somewhat been consistent even though they have formulated the definition differently. Naylor, Naim, and Berry (1999) defined that AM is about the exploitation of market knowledge and a virtual corporation to capitalize on profitable opportunities in a volatile market place. Meanwhile, Prince and Kay (2003) described that AM provides an "ability to respond to sudden changes and meet widely varied customer requirements in terms of price, specification, quality, quantity, and delivery".

To give clarity for the rest of the discussion, this paper adopts the original definition by Nagel (1992), through the famous report "21st Century Manufacturing Enterprise Strategy: An Industry-lead View": AM: "a system which contains agility as the characteristic that allows an organization to thrive in an environment of constant and unpredictable change" (Nagel, 1992).

When talking about the capabilities of the AM system, different authors tend to have different focus areas and approaches to explore. For example, the paper by Nagel (1992) addressed the capabilities of AM in nine focus areas, namely business environment, communication and information, cooperation and teaming factors, enterprise flexibility, enterprise-wide concurrency, environmental enhancement, human elements, subcontractor and supplier support, and technology deployment. Some other authors focused on the capabilities of AM based on its competitive priority areas, namely service level, lead time, cost, and quality (Christopher \& Towill, 2000; Mason-Jones, Naylor, \& Towill, 2000; Narasimhan, Swink, \& Kim, 2006).

Some authors specifically discussed the capabilities of AM based on the perspective of the innovation process and organization sustainability (Gunasekaran, 1998; Sarhadi \& Millar, 2002; D. Zhang, 2010). All in all, this paper will consider all the different focus areas and approaches mentioned above. This paper will then align and integrate them with suitable subnetworks missions, which will be elaborated in the next section.

\section{Subnetworks in the GNP}

The GPN defined as the nexus of interlinked functions, activities, and transactions through which a particular product produced, distributed, and consumed (Coe, Dicken, \& Hess, 2008). Subnetwork itself refers to a part of a com- 
pany GPN that includes a group of plants with similar manufacturing missions (Ferdows et al., 2016). Ferdows et al. (2016) delayered GPN framework into four subnetwork quadrants, which divided "based on the complexity and proprietary knowledge embedded in their products and production processes" (see Appendix). It shows the scale for assessing the complexity of the product and process by their characteristics. Further, as mentioned in the introduction part, from the four subnetworks quadrants (see Figure 1), this paper only focused on production plants in footloose and rooted subnetworks.

To give a precise analysis, below this paper provides the roles and missions of plants footloose and rooted subnetwork positions according to Ferdows et al. (2016).

\section{Footloose subnetworks}

- Includes plants that produce commodity-type products using standardized production processes in the industry (see Appendix for their characteristics).

- The primary mission for these plants is to minimize production costs while fulfilling the required quality and delivery requirements.

\section{Rooted subnetworks}

- Plants in this subnetworks produce complex and proprietary products with complex and advanced production processes (see Appendix for their characteristics).

- The plants' main mission is to be the centers of excellence for the company, signifying that they have to establish new production capabilities and share them with other plants within the company.

This paper uses the said framework because by delayering the GNP into a group of subnetworks, allows a higher level of analysis that helps to signify the focus of the plants in each subnetwork (Ferdows et al., 2016). Ferdows et al. (2016) also introduced the term "congruent", which refers to a subnetwork should have "both a coherent manufacturing mission and appropriate competencies to carry out" (Ferdows et al., 2016).

Thus, it can be related to how different capabilities carried by the AM system and their approaches able to support the missions of manufacturing plants in different subnetwork positions.

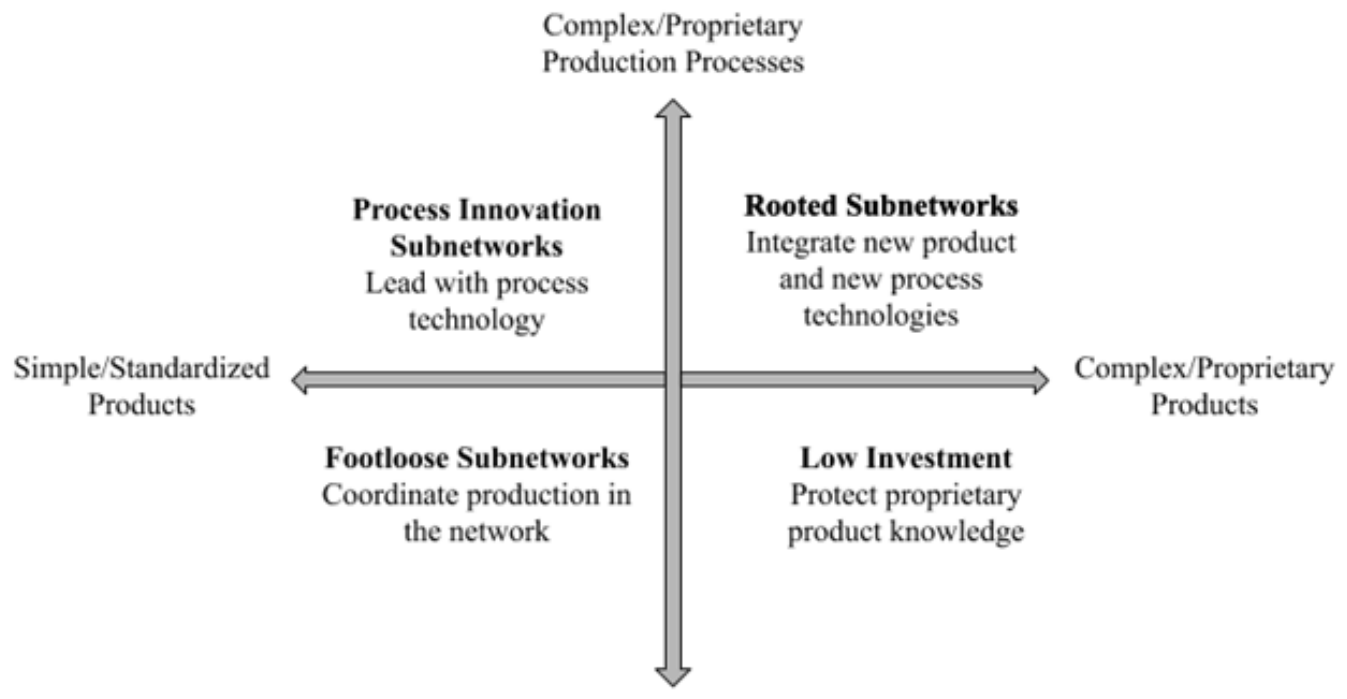

Simple/Standardized

Production Processes

FIGURE 1. Subnetworks positions framework adapted from Ferdows et al. (2016)

\section{RESEARCH METHODOLOGY}

This section provides a detailed approach to how this paper conducts a systematic literature review for AM articles. The literature review is needed to answer the research question because, through literature content analysis, this paper could identify and capture relatively objective information from the literature content (Neuendorf, 2002). However, there are criticisms regarding lacking replicability, transparency and comprehensiveness brought up by proponents such as meta-analysis against literature reviews (Tranfield, Denyer, \& Smart, 2003). To overcome the criticism above and to have a clear process structure, this paper follows an established four-step process methodology model derived from Seuring and Gold (2012). The four-step included are material collection, descriptive analysis, category selection, and material evaluation. Each of these steps elaborated further below. 


\section{Material Collection}

This first section in the methodology is where the material to be analyzed is collected, selected, and defined. University of Groningen library's SmartCat is used to start the search for quality research articles. The reason for this is because SmartCat provides direct access to central databases for articles such as Emerald, Elsevier, Taylor \& Francis, and Springer publishing groups. SmartCat also allows filtering the available literature by the database, content, format, year, and language. Knowing that AM is a large field, this paper limit the searches by only include English language literature, which are already peer-reviewed. This paper also sorts the search results based on the 'best match' option in the SmartCat.

Peer-reviewed literature is preferred because it is supposed to be a more reliable source compared to the nonpeer-reviewed one. Further, the time horizon limitation would be from the first time AM terms developed, which is in 1991, to 2019. The reason for the chosen time horizon is because this study want to make sure the precision of the analysis by including the possible shifts in the capabilities perceptions of AM over time.

As mentioned in the introduction and theory framework, the focus in this paper is to align AM capabilities and their approaches with each of the subnetworks' missions. Therefore, a few keywords used in the search engine. The first keyword used was "A M capabilities", this keyword has 299 hits. Next, the keyword "AM methodology" was used and showed 414 hits. Finally, the keyword "AM implementation" was used and showed 425 hits. Many of the literature showed in one keyword search results are also shown in the other two keywords e.g., (Cagliano \& Spina, 2000; Rao, Li, Shao, \& Shi, 2006; Vázquez-Bustelo \& Avella, 2006).
This study performed abstract selection by formulating a few criteria for suitable literature. This paper only includes the literature founded to the final set of literature if (1) it is mention agility or AM, (2) it is explicitly mentioned AM characteristics or capabilities, and (3) it provides the approach or methodology to acquire the capabilities. The reason for the rejection is because the emphasize on AM characteristics or capabilities and how to achieve them are the essential filter to decide the final set of articles since both are the main focus of this paper.

There are 35 articles included in the final set of articles. The materials were studied to understand the AM capabilities explored by the researchers. After reading all the literature, this paper finally made the final selection, with 17 articles included and used for the discussion (see Table 1). There are few reasons for not including the rest of the materials, first is because they are focused more on the supply-chain instead of the manufacturing plant itself e.g., (Huang, Uppal, \& Shi, 2002; Naylor et al., 1999). Second, some of them are focused more on the comparison of AM to other manufacturing systems such as lean manufacturing e.g., (Hallgren \& Olhager, 2009; Narasimhan et al., 2006).

\section{Descriptive Analysis}

The descriptive analysis step is about assessing the formal characteristics of the final set of the literature material. Information about the distribution of the articles across various journals is presented in Table 1 below. The year of publishing the articles are spread out, with the oldest from 1992 and the newest from 2016. The articles are coming from 11 different journals with articles from the Institute of Industrial Engineers Transactions (IIET) and International Journal of Production Research (IJPR) have the most number of articles in this paper.

TABLE 1. Descriptive characteristics of the final set of the literature material

\begin{tabular}{lc}
\hline \hline Reviewed Articles (Author(s) and Year of Publish) & Journal \\
\hline Dove (1993) & JJMARI \\
Burgess (1994) & IJOPM \\
Booth (1996) & EMJ \\
Iyer and Nagi (1997) & IIET \\
Richards (1996) & IIET \\
Devor, Graves, and Mills (1997) & IIET \\
Song and Nagi (1997) & IIET \\
Forsythe (1997) & HFEMSI \\
Gunasekaran (1998) & IJPR \\
\hline \hline
\end{tabular}




\begin{tabular}{lc} 
TABLE 1. Continue.. & \\
\hline \hline Reviewed Articles (Author(s) and Year of Publish) & Journal \\
\hline Lee (1998) & IJPR \\
Chan and Zhang (2001) & IJPR \\
Yang and Li (2002) & JMPT \\
D. Zhang (2010) & IJPR \\
Cao and Dowlatshahi (2005) & JOM \\
D. Zhang (2010) & IJPE \\
Kretschmer, Pfouga, Rulhoff, and Stjepandić (2017) & AEI \\
\hline \hline
\end{tabular}

Notes: Legend and journal count - Advanced Engineering Informatics (AEI) = 1; Engineering Management Journal (EMJ) = 1; International Journal of Advance Manufacturing Technology (IJAMT) = 1; International Journal of Operations \& Production Management $(\mathrm{IJOPM})=1$; Institute of Industrial Engineers transactions (IIET) $=4$; International Journal of Production Economy $(\mathrm{IJPE})=1$; International Journal of Production Research (IJPR) = 4; Journal of Materials Processing Technology (JMPT) = 1; Journal of Japan Management Association Research Institute (JJMARI) = 1; Journal of Operations Management (JOM) = 1; Human Factors and Ergonomics in Manufacturing \& Service Industries (HFEMSI) $=1$

\section{Category Selection}

The category selection step is about the structural dimensions applied to the final set of literature material. This paper wants to categorize the available AM capabilities with the suitable subnetworks positions based on the plants missions defined by Ferdows et al. (2016). Each of their definitions, characteristics, and missions of the subnetworks have been explained in the theorartical framework section. Additionally, to do the data extraction from the collected articles, the following steps are implemented:

1. Determining lists of AM Capabilities and how to achieve them from the collected materials.

2. Create major categories out of the capabilities lists by analyzing the capabilities category and the approach to achieve them from the articles.

3. Sort the articles into footloose or rooted subnetwork based on where they could help plants in each of the subnetworks to achieve their main missions.

\section{Material Evaluation}

The final methodology step is a material evaluation which talks about the material analysis according to the categorization. The final set of material literature have been analyzed according to steps from the previous section. The results are presented and discussed in the next sections, aiming at providing some practical implications for company managers on how AM capabilities could be used differently based on the plant's subnetwork positions in a company GPN. Finally, the data extraction with clear definitions from all the concepts enhances the reliability of the analysis.

\section{RESULTS}

This section presents the collected findings from the final selection set of literature. The focus will be on the information regarding AM capabilities and their approaches to achieve those capabilities. From a total of 17 articles, this paper unveils four major categories out of many AM capabilities lists based on the reviewed literature (e.g., responsive and system flexibility). The four capabilities category are responsiveness, flexibility, integration, and competency (see Table 2). Further, in Table 2, this paper also provide the content summary for each of the literature on how AM capabilities could help plants in different subnetwork positions (footloose and rooted) to achieve their missions. The articles are carefully classified into the most suitable subnetwork positions missions. Further, the capabilities lists included in each of the categories and their possible use to plants in footloose and rooted subnetworks are elaborated below.

\section{Responsiveness}

The first capabilities category this paper found among the reviewed literature is responsiveness. There are a total of 4 out of 17 articles in this category. This paper found that the list of capabilities included in this category are mostly on the way AM able to keep up with the dynamic environment and fulfilling customer changing demand. As for the footloose subnetworks, this paper found that plants in footloose subnetworks could use the responsiveness capabilities to increase the quality of planning results and processes (Kretschmer et al., 2017). This could be achieved simultaneously with time and cost reduction through the utilization of data mining tools (Kretschmer et al., 2017).

Meanwhile, for rooted subnetworks, responsiveness could help to keep up with competitors through constant innovations (D. Zhang, 2010). D. Zhang (2010) mentioned that the responsiveness to changes needs a few competencies such as technology and efficiency, followed by operational delivery and partnership. This way, plants in rooted subnetworks will be able to follow the competitions along multiple dimensions, including constant new changes and initiatives introduced by competitors. This paper also found 
that AM responsiveness capabilities could be used to deal with the evolving quality standard (Dove, 1993). Continuous change and rapid response could alter customer view of the quality standard (Dove, 1993). Thus, products, as well as the production process, must be structured to thrive and be responsive to change. Additionally, the responsiveness also could be used to keep up with different customer preferences (Devor et al., 1997). Devor et al. (1997) proposed a concept called multipath agility, where various functions (e.g., design, resource planning, \& manufacturing) are linked together with customers and suppliers. Article cited argue that the model of multipath agility enables the exploration of alternative resources and thus could help in selecting alternative routes to maximize the responsiveness of the entire production process.

TABLE 2. Classification of AM capabilities category with subnetwork positions based on the reviewed literature

\begin{tabular}{|c|c|c|}
\hline \multicolumn{3}{|l|}{ AM Capabilities } \\
\hline AM Capabilities Category & Footloose Subnetworks & Rooted Subnetworks \\
\hline \multirow[t]{3}{*}{ Responsiveness } & $\begin{array}{l}\text { To increase quality of planning results and processes, while } \\
\text { time and cost reduction can simultaneously be achieved } \\
\text { (Kretschmer et al., 2017). }\end{array}$ & $\begin{array}{l}\text { To keep up with the evolving product quality stan- } \\
\text { dard (Dove, 1993). }\end{array}$ \\
\hline & & $\begin{array}{l}\text { To keep up with different customer preferences } \\
\text { (Devor et al., 1997) }\end{array}$ \\
\hline & & $\begin{array}{l}\text { To stay competitive in the market through inno- } \\
\text { vation and continuous improvement (D. Zhang, } \\
\text { 2010). }\end{array}$ \\
\hline \multirow[t]{3}{*}{ Flexibility } & $\begin{array}{l}\text { To be flexible in manufacturing systems reconfiguration in- } \\
\text { cluding the relocation of machines and reassignment of op- } \\
\text { erators (Lee, 1998). }\end{array}$ & $\begin{array}{l}\text { To deliver small quantities of goods with different } \\
\text { specifications (Booth, 1996) }\end{array}$ \\
\hline & $\begin{array}{l}\text { To have reconfigurable control system for an AM cell } \\
\text { (J. Zhang, Chan, Li, Lau, \& Samaranayak, 2002). }\end{array}$ & $\begin{array}{l}\text { To be flexible on product design in mass customiza- } \\
\text { tion enterprises (Yang \& Li, 2002). }\end{array}$ \\
\hline & & $\begin{array}{l}\text { To be flexible in changing the production system } \\
\text { includes changes in the machines technology, the } \\
\text { control algorithms and structure, the system soft- } \\
\text { ware, and the system arrangement (Chan \& Zhang, } \\
\text { 2001). }\end{array}$ \\
\hline \multirow[t]{3}{*}{ Integration } & $\begin{array}{l}\text { To share resources among other companies since AM re- } \\
\text { quires resources that are over the reach of a single company } \\
\text { (Richards, 1996). }\end{array}$ & $\begin{array}{l}\text { To share resources in AM Virtual Enterprise (VE) } \\
\text { environment through Information Technology (IT) } \\
\text { (Cao \& Dowlatshahi, 2005). }\end{array}$ \\
\hline & $\begin{array}{l}\text { To have rapid adjustment in a cost-effective way through } \\
\text { collaborating with other companies. (Iyer \& Nagi, 1997) }\end{array}$ & $\begin{array}{l}\text { To achieve agility through IT-enabled processes de- } \\
\text { pending on the nature of the manufacturing out- } \\
\text { comes (Burgess, 1994) }\end{array}$ \\
\hline & & $\begin{array}{l}\text { To integrate manufacturing databases dispersed at } \\
\text { various plant sites though information system inte- } \\
\text { gration (Song \& Nagi, 1997). }\end{array}$ \\
\hline \multirow[t]{2}{*}{ Competency } & $\begin{array}{l}\text { To ensure product quality while reducing costs (Sarhadi \& } \\
\text { Millar, 2002). }\end{array}$ & $\begin{array}{l}\text { To encourage teamwork and integration of } \\
\text { partner-organizations in a physically distributed } \\
\text { manufacturing environment within a short-period } \\
\text { (Gunasekaran, 1998). }\end{array}$ \\
\hline & & $\begin{array}{l}\text { To gain maximum opportunity from the knowl- } \\
\text { edgeable and skillful human factors. (Forsythe, } \\
\text { 1997). }\end{array}$ \\
\hline
\end{tabular}

\section{Flexibility}

The capabilities lists included here are system flexibility, product design flexibility, volume flexibility, and production process flexibility. There are a total of 5 out of 17 articles that emphasized this capabilities category. From the review, this paper found that the flexibility capabilities could provide plants in footloose subnetworks to reconfigure their manufacturing systems, including the relocation of machines and reassignment of operators (Lee, 1998).
Further, the control systems for AM must be flexible and reusable for the whole system to survive changes in its environment (J. Zhang et al., 2002).

Moving on to the rooted subnetworks, this paper found that flexibility in product system, product design, volume, and product mix could help the plants in this subnetwork (Booth, 1996; Chan \& Zhang, 2001; Yang \& Li, 2002). Flexibility in changing the production system can be created using a basic building block, both hardware and software, that 
can be rearranged added or removed quickly and reliably (Chan \& Zhang, 2001). Yang and Li (2002) found that a flexible design of the product is required and has to be able to vary with the corresponding demand changes by the customers. AM flexibility capabilities also could be used to deliver products in small quantities, down to an order size of one at the right time (Booth, 1996).

\section{Integration}

This capabilities category represents the ability of AM to integrate its operation internally and externally with other parties. The list of capabilities included here are cooperation and information sharing. There are a total of 5 out of 17 articles included there. The integration capabilities in footloose subnetworks could be used to have a rapid adjustment in an economical way (Iyer \& Nagi, 1997). One of the key elements to achieve this is to collaborate with other companies and by sharing information, resources, and capabilities (Iyer \& Nagi, 1997).

Additionally, integration capabilities could be used to share resources and technologies among other companies. This is because AM requires resources that are beyond the reach of a single company (Richards, 1996). Moving on to the rooted subnetworks, Burgess (1994) proffered that integration through IT-enabled processes could be used to achieving agility. Additionally, rooted subnetworks could use the integration capabilities to share resources, including knowledge to other plants (Song \& Nagi, 1997; Cao \& Dowlatshahi, 2005). Cao and Dowlatshahi (2005) mentioned that resource sharing is a dimension of a VE that is most affected by the use of IT. This indicates that IT facilitates the use of resources sharing in the VE environment.

\section{Competency}

This capabilities category covers the ability of AM to provide the manufacturing plant with productivity, efficiency, and effectiveness in meeting its goals. Capabilities lists this paper found here are related to product quality and human resources skills. There are a total of 3 out of 17 articles that included in this capabilities category. This paper found that plants in the footloose subnetworks could use AM competency capabilities to produce and ensure product quality while reducing costs. Sarhadi and Millar (2002) inferred that AM competencies could be boosted with digital platforms that pervading all functions and departments within a company. The digital platforms support the ideas defined for AM and also provide the capabilities to manage the supply chain.

Meanwhile, this paper found that competency capabilities that could be used in the rooted subnetworks emphasized more on the human factors area. Knowledgeable workers with adequate skills are one of the critical aspects of AM companies (Forsythe, 1997; Gunasekaran, 1998). Further, Gunasekaran (1998) recommended adopting a matrix organizational structure that may facilitate a team working by smooth information flow between plants. Additionally, training and education, employee empowerment, and leadership are required to support agility in manufacturing organizations (Forsythe, 1997; Gunasekaran, 1998).

\section{DISCUSSION}

In this section, this paper elaborated the findings section by talking about the AM capabilities from the previous section in relation to the footloose and rooted subnetworks separately. By doing so, this paper will then attempt to answer our research question in this section. The research question is, how does the use AM capabilities differ within the context of plants in footloose and rooted subnetwork positions of the GNP. In this work, this paper found that the AM capabilities could be used differently depending on the focus areas emphasized in each category, which will be elaborated below.

\section{Responsiveness Capabilities: Differ Based on the Prior- ity Dimension to Response}

It was observed that the capabilities category of responsiveness that could be used in footloose and rooted subnetworks are differ based on their priority dimensions. Plants in footloose subnetworks emphasize on cost reduction while still meeting required specifications (Ferdows et al., 2016). Therefore an approach for being responsive while still prioritize the cost minimization dimension is preferred for this subnetwork (Kretschmer et al., 2017). Meanwhile, plants in rooted subnetworks tend to emphasize more on integrating new products with new production technologies to stay in the rooted subnetwork positions (Ferdows et al., 2016). Accordingly, the responsiveness approach that prioritizes the dimension of continuous improvement is more suitable for rooted subnetworks (D. Zhang, 2010).

Additionally, among the reviewed literature, this paper found that quality and customer preference are also addressed as the priority dimensions (Dove, 1993; Devor et al., 1997). Quality becomes important when continuous change and rapid response alter customer perceptions of the things they have purchased (Dove, 1993). Companies then will either have a short life or will have products and services that address life-cycle values in a con- 
tinuous changing environment (Dove, 1993). Further, the approach in customer preference dimension (Devor et al., 1997), is suitable to help plants in the rooted subnetwork to accommodate many product variations at once. This is in line with the product characteristic of rooted subnetworks where product variations is emphasized more compared to footloose subnetworks (see Appendix).

\section{Flexibility Capabilities: Differ Based on the Product and Process Flexibility Focus}

From the reviewed literature, the capabilities category of flexibility in footloose and rooted subnetworks are differ based on the focus on product and process flexibility. Plants in footloose subnetwork produced commodity-type of product with standardized production process (Ferdows et al., 2016). Among the reviewed AM literature, this paper could not find any product flexibility focus approach for footloose subnetworks. However, this paper found that the process flexibility focus for footloose subnetwork is mainly regarding machine relocations and system reusability (Lee, 1998; J. Zhang et al., 2002). This is in line with the process characteristics of standard production processes is that production can be easily and quickly transferred from one plant to another (see Appendix).

On the other hand, plants in rooted subnetworks produced unique products with advanced production process (Ferdows et al., 2016). From the reviewed literature, the product flexibility here focused on product customizations (Booth, 1996; Yang \& Li, 2002). This corresponds with the characteristics of rooted subnetworks where there are many product variations, choice of features, and special materials. Meanwhile, the process flexibility focused on the production system changes (Chan \& Zhang, 2001). This flexibility focus fits with the process characteristics of the subnetworks, where process innovation is frequent and highly emphasized (see Appendix).

\section{Integration Capabilities: Differ Based on the Risk of In- formation Sharing}

Among the reviewed AM literature, this paper found that the integration capabilities category differs in footloose and rooted subnetworks based on the level of the risk of information sharing. This could also be related to the needs of internal and external integration. Production know-how in footloose subnetworks is highly codified and widely available in the industry (Ferdows et al., 2016). Therefore, they tend to have a low proprietary production know-how level. They are then able to share resources, information, and collaborating with external companies without the risk of los- ing their essential resources. In fact, most of the plants in this subnetwork are most likely to be outsourced (Ferdows et al., 2016). Thus, the external integration capabilities of AM emphasized in this subnetwork (Iyer \& Nagi, 1997; Richards, 1996).

Meanwhile, plants in rooted subnetwork tend to be exposed to high risks from sharing information with external parties. This is because they have high proprietary production know-how level, given that their nature of having a sophisticated and proprietary production process. However, plants in this subnetworks have roles as the centers of excellence, where they have to develop new production know-how and shared it with other plants within the company (Ferdows et al., 2016). Therefore, the internal information sharing is more emphasized here. From the reviewed AM literature, the internal integration could be done using virtual enterprise, IT-enabled process, and information system (Burgess, 1994; Cao \& Dowlatshahi, 2005; Song \& Nagi, 1997).

\section{Competency Capabilities: Differ Based on the Needs of Cost Efficiency and Skillful Workforces}

The factor that makes the competency capabilities category differ between footloose and rooted subnetworks is the need for cost efficiency and skilled workforces. From the reviewed literature, this paper found how AM competency could help footloose subnetworks to ensure product quality while reducing costs (Sarhadi \& Millar, 2002). This corresponds with the primary missions of footloose subnetworks to have cost efficiency while meeting the quality and delivery time requirement (Ferdows et al., 2016). Further, Plants in footloose subnetworks produce common products with the standard production process (Ferdows et al., 2016). Therefore they do not need highly skilled workers to be able to operate smoothly.

As for rooted subnetworks, cost efficiency is not their main priority. Instead, knowledgeable and skillful human factors are needed (Ferdows et al., 2016). This is because plants in rooted subnetworks need skilled workforces to deal with their nature of complex products and production processes. Additionally, they also need knowledgeable workforces to fulfill their role as centers of excellence. This is in line with what this paper found from the reviewed literature, where AM also identical with knowledgeable and skillful human factors to keep up with unexpected changes in the business environment (Forsythe, 1997; Gunasekaran, 1998).

\section{CONCLUSION}

This paper conducted a research study based on literature review. Our main goal was to analyze how AM capabili- 
ties differ in footloose and rooted subnetworks. To be able to meet our objective, this paper align the AM capabilities from reviewed literature with suitable subnetworks missions from the paper by Ferdows et al. (2016). The total number of literature that this paper has reviewed and discussed is 17. From the reviewed literature, this paper found that there are four major AM capabilities categories, namely, responsiveness, flexibility, integration, and competency. Further, all of the four AM capabilities categories could be used differently in footloose and rooted subnetworks.

Subsequently, this paper also found that the use of each of the AM capabilities categories differs based on several factors of the two subnetworks (footloose and rooted). In the responsiveness category, the capabilities differ on the addressed priority dimensions to response. There, footloose could prioritize the use of AM capabilities to be responsive with cost minimization while rooted with quality and customer preference dimensions. The flexibility category could be used differently based on the product and production process flexibility focus. Over there, footloose focused on relocations and reusability of production process capabilities, while rooted focused on product customization and production system change capabilities.

Further, the integration category differs due to the risks of information sharing, which is higher in rooted compared to footloose due to their higher possession of proprietary knowledge. With that, footloose could emphasize the use of external integration capabilities more, while rooted in internal integration capabilities use more. Finally, the competency capabilities category differs on the needs of costefficiency and skillful workforces. There, this paper found that footloose could use the AM capabilities here to have cost-efficiency, while rooted to have skillful workforces. Further, the implications of the findings and discussions are presented in the next section.

\section{Implications}

Given all of the information above, this paper have derived several theoretical and managerial implications. There are two theoretical implications from this study. First, this paper has presented an approach on how AM system capa- bilities could be related with GPN by using Ferdows et al. (2016) delayered GPN framework. Second, this study provides an early phase to understand how AM system could accommodates different plants positions in the GPN.

Moving on, this study have derived three managerial implications. First, this study provides an insight of how AM capabilities could help plants in the footloose and rooted subnetworks to achieve their respective missions. Further, this paper also have described how AM capabilities differ between the production plants in the two subnetworks. To this, companies with AM system could know which AM Capabilities factors should be maximized in the respective plants subnetworks. Finally, this paper set out an insight that, despite being founded 29 years ago, AM system with their capabilities, is still relevant to be continuously implemented in the present time.

In this section, the limitations along sides with the agenda for future research are presented. First, the findings about the AM capabilities that could be used in the different subnetworks are still in general approach. Thus, while the findings are most likely be applicable for many companies, they might not be the case for some companies due to unseen external factors. To address this limitation, industrial questionnaire surveys and case studies of plants are recommended for future research. It would also be interesting to conduct a research on assessing the possible external factors that might cause the use of AM capabilities in the specific companies subnetworks differ.

Second, from the findings, it was observed that capabilities are sometimes overlapped. One capability may lead to the enhancement of other capabilities and vice versa. Thus, the limitation here is that the line between each of the different capabilities categories becomes a bit unclear. Accordingly,this paper encourage future research to develop a methodology or a framework on how to clearly differentiate the categories of AM capabilities. Further, this paper does not provide any empirical validation yet for the findings. Thus, this paper also encourages future research to conduct an empirical validation. This might be done by using a qualitative method by interviewing companies from the two different subnetworks (footloose and rooted).

\section{REFERENCES}

Boonvut, S. (2017). The quality financial statements of Small and Medium Enterprises Business (SME's) in view of the tax auditor. International Journal of Business and Economic Affairs, 2(6), 335-340. doi:https://doi.org/10.24088/ ijbea-2017-26002

Booth, R. (1996). Agile manufacturing. Engineering Management Journal, 6(2), 105-112. doi:https://doi.org/10.1049/em: 19960206 
Burgess, T. F. (1994). Making the leap to agility. International Journal of Operations \& Production Management, 14(11), 23-34. doi:https://doi.org/10.1108/01443579410068620

Cagliano, R., \& Spina, G. (2000). How improvement programmes of manufacturing are selected. International Journal of Operations \& Production Management, 20(7), 772-792. doi:https://doi.org/10.1108/01443570010330748

Cao, Q., \& Dowlatshahi, S. (2005). The impact of alignment between virtual enterprise and information technology on business performance in an agile manufacturing environment. Journal of Operations Management, 23(5), 531-550. doi:https://doi.org/10.1016/j.jom.2004.10.010

Chan, F. T., \& Zhang, J. (2001). Modelling for agile manufacturing systems. International Journal of Production Research, 39(11), 2313-2332. doi:https://doi.org/10.1080/00207540110051932

Christopher, M., \& Towill, D. R. (2000). Supply chain migration from lean and functional to agile and customised. Supply Chain Management: An International Journal, 5(4), 206-213. doi:https://doi.org/10.1108/13598540010347334

Coe, N. M., Dicken, P., \& Hess, M. (2008). Global production networks: Realizing the potential. Journal of Economic Geography, 8(3), 271-295. doi:https://doi.org/10.1093/jeg/lbn002

Devor, R., Graves, R., \& Mills, J. J. (1997). Agile manufacturing research: Accomplishments and opportunities. IIE Transactions, 29(10), 813-823. doi:https://doi.org/10.1080/07408179708966404

Dove, R. (1993). What is talk about agility? Journal of Japan Management Association Research Institute, 34(6), 55-60.

Dubey, R., \& Gunasekaran, A. (2015). Agile manufacturing: Framework and its empirical validation. The International Journal of Advanced Manufacturing Technology, 76(9-12), 2147-2157. doi:https://doi.org/10.1007/s00170-014-6455-6

Ferdows, K. (2008). Managing the evolving global production network. Oxford, UK: Oxford University Press.

Ferdows, K., Vereecke, A., \& De Meyer, A. (2016). Delayering the global production network into congruent subnetworks. Journal of Operations Management, 41, 63-74. doi:https://doi.org/10.1016/j.jom.2015.11.006

Forsythe, C. (1997). Human factors in agile manufacturing: A brief overview with emphasis on communications and information infrastructure. Human Factors and Ergonomics in Manufacturing \& Service Industries, 7(1), 3-10. doi:https:// doi.org/10.1002/(sici)1520-6564(199724)7:1<3::aid-hfm1>3.0.co;2-7

Goldman, S. L., Nagel, R. N., \& Preiss, K. (1995). Agile competitors and virtual organizations: Strategies for enriching the customer. New York, NY: Van Nostrand Reinhold.

Gunasekaran, A. (1998). Agile manufacturing: Enablers and an implementation framework. International Journal of Production Research, 36(5), 1223-1247. doi:https://doi.org/10.1080/002075498193291

Hallgren, M., \& Olhager, J. (2009). Lean and agile manufacturing: External and internal drivers and performance outcomes. International Journal of Operations \& Production Management, 29(10), 976-999. doi:https://doi.org/10.1108/ 01443570910993456

Huang, S. H., Uppal, M., \& Shi, J. (2002). A product driven approach to manufacturing supply chain selection. Supply Chain Management: An International Journal, 7(4), 189-199. doi:https://doi.org/10.1108/13598540210438935

Iyer, S., \& Nagi, R. (1997). Automated retrieval and ranking of similar parts in agile manufacturing. IIE Transactions, 29(10), 859-876. doi:https://doi.org/10.1080/07408179708966407

Kretschmer, R., Pfouga, A., Rulhoff, S., \& Stjepandić, J. (2017). Knowledge-based design for assembly in agile manufacturing by using data mining methods. Advanced Engineering Informatics, 33(10), 285-299. doi:https://doi.org/10.1504/ ijasm.2017.10009458

Lee, G. (1998). Designs of components and manufacturing systems for agile manufacturing. International Journal of Production Research, 36(4), 1023-1044. doi:https://doi.org/10.1080/002075498193507

Luekveerawattana, R. (2016). Relationship between personal factors and marketing mix satisfaction of the tourists at Don Hoi Lot in Samutsongkham province, Thailand. Journal of Administrative and Business Studies, 2(3), 113-120. doi:https://doi.org/10.20474/jabs-2.3.2

Mason-Jones, R., Naylor, B., \& Towill, D. R. (2000). Lean, agile or leagile? Matching your supply chain to the marketplace. International Journal of Production Research, 38(17), 4061-4070. doi:https://doi.org/10.1080/00207540050204920

Nagel, R. N. (1992). 21st century manufacturing enterprise strategy report (Tech. Rep.). Defense Technical Information Center, Hague, Neitherland.

Narasimhan, R., Swink, M., \& Kim, S. W. (2006). Disentangling leanness and agility: An empirical investigation. Journal of Operations Management, 24(5), 440-457. doi:https://doi.org/10.1016/j.jom.2005.11.011 
Naylor, J. B., Naim, M. M., \& Berry, D. (1999). Leagility: Integrating the lean and agile manufacturing paradigms in the total supply chain. International Journal of Production Economics, 62(1-2), 107-118. doi:https://doi.org/10.1016/ s0925-5273(98)00223-0

Neuendorf, K. A. (2002). Defining content analysis. Thousand Oaks, CA: Sage.

Nuriansyah, S., Juniar, A., \& Redawati, R. (2017). Factors affecting dividend payout ratio of food and beverage manufacturing companies in Indonesia. International Journal of Business and Administrative Studies, 3(6), 229-238. doi:https:// doi.org/10.20469/ijbas.3.10004-6

Prince, J., \& Kay, J. (2003). Combining lean and agile characteristics: Creation of virtual groups by enhanced production flow analysis. International Journal of Production Economics, 85(3), 305-318. doi:https://doi.org/10.1016/s0925 -5273(03)00118-x

Rao, Y., Li, P., Shao, X., \& Shi, K. (2006). Agile manufacturing system control based on cell re-configuration. International Journal of Production Research, 44(10), 1881-1905. doi:https://doi.org/10.1080/00207540500410002

Richards, C. W. (1996). Agile manufacturing: Beyond lean? Production and Inventory Management Journal, 37(2), 60-64.

Sarhadi, M., \& Millar, C. (2002). Defining a framework for information systems requirements for agile manufacturing. International Journal of Production Economics, 75(1-2), 57-68. doi:https://doi.org/10.1016/s0925-5273(01)00181-5

Seuring, S., \& Gold, S. (2012). Conducting content-analysis based literature reviews in supply chain management. Supply Chain Management: An International Journal, 17(5), 544-555. doi:https://doi.org/10.1108/13598541211258609

Sharifi, H., \& Zhang, Z. (2001). Agile manufacturing in practice-application of a methodology. International Journal of Operations \& Production Management, 21(5/6), 772-794. doi:https://doi.org/10.1108/01443570110390462

Song, L., \& Nagi, R. (1997). Design and implementation of a virtual information system for agile manufacturing. IIE Transactions, 29(10), 839-857. doi:https://doi.org/10.1080/07408179708966406

Tan, B. (1998). Agile manufacturing and management of variability. International Transactions in Operational Research, 5(5), 375-388. doi:https://doi.org/10.1111/j.1475-3995.1998.tb00121.x

Tranfield, D., Denyer, D., \& Smart, P. (2003). Towards a methodology for developing evidence-informed management knowledge by means of systematic review. British Journal of Management, 14(3), 207-222. doi:https://doi.org/10.1111/ 1467-8551.00375

Vázquez-Bustelo, D., \& Avella, L. (2006). Agile manufacturing: Industrial case studies in Spain. Technovation, 26(10), 1147-1161. doi:https://doi.org/10.1016/j.technovation.2005.11.006

Yang, S., \& Li, T. (2002). Agility evaluation of mass customization product manufacturing. Journal of Materials Processing Technology, 129(1-3), 640-644. doi:https://doi.org/10.1016/s0924-0136(02)00674-x

Yusuf, Y., Sarhadi, M., \& Gunasekaran, A. (1999). Agile manufacturing. International Journal of Production Economics, 62(1-2), 33-43. doi:https://doi.org/10.1016/s0925-5273(98)00219-9

Zhang, D. (2010). Towards theory building in agile manufacturing strategies: Case studies of an agility taxonomy. International Journal of Production Economics, 131(1), 303-312. doi:https://doi.org/10.1016/j.ijpe.2010.08.010

Zhang, J., Chan, F. T. S., Li, P., Lau, H. C. W., \& Samaranayak, P. (2002). Investigation of the reconfigurable control system for an agile manufacturing cell. International Journal of Production Research, 40(15), 3709-3723. doi:https://doi.org/ $10.1080 / 00207540210159554$ 


\section{APPENDIX}

Appendix: Product and process characteristics adapted from Ferdows et al. (2016)

\begin{tabular}{|c|c|}
\hline Product Characteristics & Comnlex and Pronrietary Products \\
\hline "Very infrequent introduction of new products" & "Very frequent introduction of new product" \\
\hline "Very few marginal changes made in existing products" & $\begin{array}{l}\text { "Very frequent major changes in product, differentiating it } \\
\text { from competitors products" }\end{array}$ \\
\hline "Simple and product design" & "Complex product design" \\
\hline $\begin{array}{l}\text { "Standard and widely available raw materials and compo- } \\
\text { nents" }\end{array}$ & $\begin{array}{l}\text { "R\&D-intensive materials and components" "Few product } \\
\text { variations and choice of features, shapes, colors, materials, } \\
\text { etc." "Many product variations, choice of features, complex } \\
\text { shape, special materials, etc." }\end{array}$ \\
\hline \multicolumn{2}{|l|}{ Process Characteristics } \\
\hline Commodity Products & Complex and Proprietary Products \\
\hline $\begin{array}{l}\text { "Production know-how is highly codified and widely avail- } \\
\text { able in the industry" }\end{array}$ & "Production know-how is mostly in tacit form" \\
\hline $\begin{array}{l}\text { "Production can be easily and quickly transferred from one } \\
\text { plant to another" }\end{array}$ & $\begin{array}{l}\text { "Level of experience can differentiate the process between } \\
\text { competitors" }\end{array}$ \\
\hline "Changes in production processes are very infrequent" & $\begin{array}{l}\text { "Transfer of production from one plant to another is } \\
\text { difficult" }\end{array}$ \\
\hline "Process innovations are rare" & "Process innovation is frequent and highly emphasized" \\
\hline "Most process technologies are developed outside the firm" & $\begin{array}{l}\text { "Significant new process technologies are developed in- } \\
\text { house" }\end{array}$ \\
\hline "Equipment and machinery are highly standardized" & $\begin{array}{l}\text { "Significant portion of equipment and machinery are de- } \\
\text { signed in-house" }\end{array}$ \\
\hline
\end{tabular}

